\title{
PENGARUH MODEL PEMBELAJARAN DAN MINAT BACA TERHADAP HASIL BELAJAR APRESIASI PUISI
}

\author{
Wienike Dinar Pratiwi ${ }^{1}$, Uah Maspuroh ${ }^{2}$ \\ Universitas Singaperbangsa Karawang \\ Surel: wienike,dinar@fkip.unsika.ac.id ${ }^{\mathbf{1}}$ \\ uah.maspuroh@fkip.unsika.ac.id ${ }^{2}$
}

\begin{abstract}
Abstrak
Tujuan dari penelitian ini adalah untuk mengetahui: 1) Pengaruh model pembelajaran contextual teaching learning (CTL) terhadap hasil belajar apresiasi puisi. 2). Pengaruh minat membaca terhadap hasil belajar apresiasi puisi. 3).Pengaruh interaktif antara model pembelajaran contextual teaching learning (CTL) dan minat membaca terhadap hasil belajar apresiasi puisi. Metode yang digunakan dalam penelitian adalah metode eksperimen. Populasi dalam penelitian ini adalah seluruh siswa Kelas VII Sekolah Menengah Pertama (SMP) Negeri di Kabupaten Karawang Tahun Ajaran 2015 - 2016 dengan jumlah siswa 472 yang terbagi dalam 14 kelas paralel. Sampel yang digunakan dalam penelitian ini berjumlah 44 siswa yang terbagi menjadi dua kelompok, 22 siswa kelompok eksperimen dan 22 siswa kelompok kontrol. Hasil penelitian terdapat pengaruh yang signifikan model pembelajaran CTL terhadap hasil belajar apresiasi puisi. Hal tersebut dapat dibuktikan dengan nilai Sig $=0,000(<0.05)$, maka terdapat perbedaan yang signifikan terhadap hasil belajar apresiasi puisi pada penerapan model pembelajaran kontekstual dan model pembelajaran konvensional. Terdapat pengaruh yang signifikan minat baca terhadap hasil belajar apresiasi puisi. Hal tersebut dapat dibuktikan dengan nilai sig $=0,000$ $(<0.05)$ yang berarti terdapat perbedaan yang signifikan terhadap hasil belajar apresiasi puisi pada siswa yang memiliki minat baca tinggi dan rendah.Hasil belajar apresiasi puisi yang diberi model pembelajaran kontekstual pada siswa yang memiliki minat baca tinggi memiliki nilai rata-rata tertinggi, sedangkan nilai terendah terjadi pada kelompok yang diberi model pembelajaran konvensional dengan minat baca rendah.
\end{abstract}

Kata Kunci : Model CTL, minat baca, apresiasi puisi. Pendidikan Balnasa, Sastra Abstract

The purpose of this study was to find out: 1) The influence of the contextual teaching learning (CTL) learning model on the results of poetry appreciation learning. 2). Effect of interest in reading on the results of poetry appreciation learning. 3). Interactive influence between the learning model of contextual teaching learning $(C T L)$ and interest in reading towards the results of poetry appreciation learning.

The method used in the research is the experimental method. The population in this study were all Grade VII students of State Junior High School in Karawang Regency Academic Year 2015-2016 with a total of 472 students divided into 14 parallel classes. The sample used in this study amounted to 44 students divided into two 
groups, 22 students in the experimental group and 22 students in the control group. The results of the study have a significant influence on the CTL learning model on the results of poetry appreciation learning. This can be proven by the Sig value = $0,000(<0.05)$, so there are significant differences in the poetry appreciation learning outcomes in the application of contextual learning models and conventional learning models. There is a significant effect of reading interest on the results of poetry appreciation learning. This can be proven by the sig value $=0,000(<0.05)$ which means that there are significant differences in poetry appreciation learning outcomes for students who have high and low reading interest. Poetry appreciation learning results are given a contextual learning model for students who have high reading interest. has the highest average value, while the lowest value occurs in groups given conventional learning models with low reading interest.

Keywords: CTL model, reading interest, poetry appreciation.

\section{PENDAHULUAN}

Pendidikan merupakan proses yang memungkinkan peserta didik mengembangkan kemampuan, sikap, dan bentukbentuk tingkah laku lainnya di dalam masyarakat tempat ia hidup, sehingga dapat memperoleh atau mengalami peningkat kompetensi sebagai kebutuhan hidup di dalam masyarakat. Negara melalui pemerintah merencanakan, menyelenggarakan, bahkan mengevaluasi pelaksanaan pendidikan demi memenuhi kebutuhan sumber daya manusia. Perencanaan maupun pelaksanaan pendidikan dimaksudkan untuk meningkatkan kualitas manusia secara utuh, meliputi dimensi kognitif intelektual, keterampilan, dan nilai-nilai lainnya. Pendidikan formal maupun non formal diselenggarakan untuk memenuhi kebutuhan masyarakat di Ibidang pendidikan agar dapat hidup layak dan berkompetisi dengan warga Negara Indonesia maupun sebagai warga dunia di era globalisasi.

Pendidikan formal di sekolah mulai dari Pendidikan Dasar sampai Pendidikan Tinggi wajib menyelenggarakan atau melatih peserta didik dengan bermacam-macam kompetisi yang sudah diatur atau ditentukan dalam kurikulum secara berjenjang sesuai Standar Kompetensi dan Kompetensi Dasar yang relevan pada setiap mata pelajaran Satuan Pendidikan Tingkat Sekolah Menengah Pertama wajib membekali peserta didik dengan berbagai ilmu pengetahuan, keterampilan, dan nilai-nilai moral mulai dari Pendidikan Agama, Pendidikan Kewarganegaraan, Bahasa Indonesia, Bahasa Inggris, Ilmu Pengetahuan Alam, Ilmu Pengetahuan Sosial, Pendidikan Jasmani dan Kesehatan, Seni Budaya, dan beberapa pendidikan keterampilan lainyang sesuai dengan kebutuhan, lingkungan, usia, maupun bakat peserta didik. Pembekalan-pembekalan berbagai ilmu dan keterampilan tersebut diselenggarakan dalam kegiatan intrakurikuler maupun ekstrakurikuler. Hal itu semua diatur dan dilaksanakan demi membantu atau membentuk peserta didik menjadi pribadi yang terampil, unggul dan tangguh.

Segala perencanaan, usaha, dan strategi pembelajaran yang dilakukan guru, siswa maupun pemerintah bertujuan melatih keterampilan siswa pada bidang-bidang tersebut. Demikian juga pembelajaran apreasiasi sastra dituangkan atau dilaksanakan dalam 
bentuk keterampilan membaca, menyimak, berbicara, dan menulis. Keterampilan berbahasa hanya dapat dicapai atau diperoleh dengan jalan praktik dan banyak latihan.

Keterampilan membaca dapat dicapai atau semakin berkembang bila kegiatan membaca sering dilakukan atau dengan intensitas tinggi. Demikian juga keterampilan menyimak, berbicara dan menulis harus mendapat perhatian para pendidik disekolah untuk memberi kesempatan berlatih atau praktik langsung agar dapat menciptakan peserta didik yang terampil dan handal.

Dalam pemberian nilai Bahasa Indonesia sebagai laporan hasil belajar siswa yang tercantum di rapor pernah dibedakan atau diberi pada masingmasing aspek. Nilai membaca, menulis, menyimak, dan berbicara masing masing dirinci tersendiri (KBK 2004). Dari pengalaman penulis mengajar maupun data daftar nilai Bahasa Indonesia beberapa SMP di Karawang, nilai ratarata menulis dan membaca lebih rendah dari nilai rata-rata menyimak, dan berbicara.

Pemberian nilai dalam rapor maupun pelaksanaan pembelajaran, keempat keterampilan berbahasa tersebut tidak dikotak-kotakan melainkan terintegrasi. Hal ini memang memberi pengaruh terhadap ketidakjelasan secara nyata tentang gambaran keterampilan yang dimiliki siswa atas keempat bidang keterampilan berbahasa seperti dibicarakan di atas. Dalam kenyatan penggunaan maupun proses pembelajaran, empat keterampilan berbahasa itu memang berbeda. Proses dan bentuk kegiatan membaca berbeda dengan proses dan bentuk kegiatan menulis, berbeda dengan proses dan bentuk kegiatan menyimak, berbeda pula dengan proses dan bentuk kegiatan berbicara, minat, motivasi, dan kemampuan peserta didik maupun masyarakat pada keempat aspek itu pun berbeda. Umumnya peserta didik lebih menyukai pembelajaran menyimak/ mendengarkan dari pada berbicara, lebih menyukai pembelajaran membaca dari pada menulis.

Tindakan dan kegiatan berbahasa secara reseptif membaca, menyimak lebik banyak terjadi dari pada tindakan berbahasa secara produktif menulis dan berbicara. Menikmati karya orang lain lebih mudah dan lebih banyak dilakukan dari pada menciptakan atau berkarya untuk dinikmati orang lain. Menulis merupakan suatu materi yang dianggap sulit dan jarang dilakukan. Siswa terlihat merasa terpaksa dengan tugas dan kegiatan menulis. Jika ada lomba atau sayembara menulis atau membuat karya ilmiah peminatnya masih sedikit.

Dalam proses belajar mengajar di sekolah, khususnya pembelajaran Bahasa Indonesia, walaupun membaca lebih mudah dan lebih diminati peserta didik, tetapi minat baca siswa masih sangat rendah. Dari daftar pengunjung maupun peminjam buku di perpustakaan sekolah terlihat jumlah yang sangat kecil dibandingkan dengan jumlah siswa keseluruhan. Bahkan siswa yang ditugasi membaca artikel dari koran atau materi i fain biasanya hanya beberapa orang saja yang melakukannya.

\section{METODE}

Penelitian ini dilaksanakan pada Sekolah Menengah Pertama Negeri (SMPN) di Karawang. Yaitu pada SMPN 3 dan SMPN 8 Kabupaten Karawang, dilaksanakan pada semester 2 tahun pembelajaran 2015-2016 tepatnya pada bulan Februari - Juni 2016.

Penelitian menggunakan metode eksperimen, yaitu dengan memberikan 
jenis perlakuaan yang berbeda pada dua kelompok belajar siswa. Kelompok yang satu dijadikan sebagai kelompok eksperimen, yaitu diberikan perlakuan (treatment) model pembelajaran dengan media CTL, sedangkan kelompok lainnya sebagai kelompok kontrol dengan perlakukan (treatment) pembelajaran menulis eksposisi mengunakan metode konvensional. Dari masingmasing kelompok tersebut, kemudian dibagi dalam 2 (dua) katagori kelompok siswa yang didasarkan atas tingkat minat baca siswa yang dimiliki, yaitu kelompok siswa dengan minat baca tinggi dan kelompok siswa dengan minat baca rendah.

Desain faktorial digunakan apabila ada dua atau lebih variabel dengan masing-masing variabel memiliki lebih dari satu situasi. Pada eksperimen ini tentang pendekatan model pembelajaran cara pertama $\left(\mathrm{A}_{1}\right)$, yakni dengan menggunakan model pembelajaran CTL dan cara kedua (A2), dengan konvensional, pada siswa dengan minat baca tinggi (B1) dan siswa dengan minat baca rendah (B2). Karena ada dua cara pada masing-masing variabel maka disebut dengan 2 × 2 factorial design. (Ronny Kountur, 2007:140).

\section{HASIL DAN PEMBAHASAN}

Hasil analisis deksriptif pada Tabel Descriptive Statistic, menggambarkan rata-rata dan simpangan baku hasil belajar pada pemberian model pembelajaran berdasarkan model kontekstual dan konvensional dan minat baca kategoriminat baca tinggi dan minat baca rendah.

Menurut

(2001:132).

Muhibbin

mempengaruhi belajar siswa dapat dibedakan menjadi tiga macam, yaitu 1) faktor internal /faktor dalam diri siswa) yakni keadaan atau kondisi jasmani dan rohani, 2) faktor eksternal (faktor dari luar siswa) yakni kondisi lingkungan di sekitar siswa, dan 3) faktor pendekatan belajar (aproach to learning), yakni jenis upaya belajar siswa yang meliputi strategi dan model yang digunakan siswa untuk melakukan kegiatan pembelajaran materi-materi pelajaran.

Hasil penelitian untuk kategori pemberian model pembelajaran kontekstual pada siswa dengan minat baca tinggi memiliki nilai rata-rata hasil belajar lebih tinggi dibandingkan nilai rata-rata hasil belajar siswa dengan minat baca rendah.

Untuk kategori pemberian model pembelajaran konvensional dengan minat baca tinggi memiliki nilai rata-rata hasil belajar lebih tinggi dibandingkan dengan kelompok siswa dengan minat baca rendah.

Tabel test of Between-Subject Effects merupakan tabel utama yang mempresentasikan hasil hipotesis yang diajukan peneliti. Dari tabel tersebut, diketahui nilai $\mathrm{p}$-value untuk kategori model adalah $0,000 \quad(<0,05)$, maka kesimpulannya terdapat perbedaan yang signifikan terhadap Hasil belajar apresiasi puisi pada penerapan model pembelajaran kontekstual dan model pembelajaran konvensional.

Hasil belajar apresiasi puisi dipengaruhi oleh faktor penerapan model pembelajaran salah satunya adalah penerapan model pembelajaran kontekstual (CTL). Pembelajaran kontekstual menurut Wilson (2001) adalah suatu konsep bagi pembelajaran yang menolong guru dalam menghubungkan topik yang diajarkan dengan situasi dunia nyata, sedangkan bagi siswa sebagai motivasi untuk membuat pengaitan antara pengetahuan dengan kehidupannya baik di keluarga, masyarakat 
dan akitivitas lainnya. Sedangkan dalam pembelajaran konvensional, siswa cenderung pasif dalam menerima pelajaran dan gurunya cenderung aktif dalam pengajarannya, siswa kurang mendapatkan pengalaman belajar secara mendalam.

Hasil pengujian untuk kategori minat baca memiliki nilai sig $0.000(<0,05)$ yang berarti terdapat perbedaan yang signifikan hasil belajar apresiasi puisi dengan minat baca tinggi dan rendah. Sangat jelas bahwa minat baca memiliki peran yang sangat penting dalam meningkatkan hasil belajar apresiasi puisi. Seseorang dengan yang memiliki minat baca tinggi akan memiliki hasil belajar apresiasi puisi yang tinggi bila dibandingkan siswa yang memiliki minat baca rendah.

Selanjutnya dari tabel test of Between-Subject Effects tersebut juga diketahui nilai p-value untuk interaksi model pembelajaran CTLdan minat baca (model *minat) adalah $0,001(<0,05)$, maka kesimpulannya terdapat perbedaan signifikan faktor interaksi kategori model pembelajaran dengan minat baca.

Minat baca yang melekat pada diri mereka sebaiknya memiliki kesinambungan dengan model pembelajaran yang diterapkan oleh guru agar hasil belajar apresiasi puisi mereka mendapat hasil seperti yang diharapkan. Jurnal Ir

Berdasarkan teori tersebut dapat diartikan bahwa pemberian model pembelajaran yang dapat meningkatkan hasil belajar apresiasi puisi. Siswa dengan berbagai latar belakang seperti yang memiliki minat baca tinggi maupun rendahdalam penelitian ini mampu meningkatkan hasil belajar apresiasi puisi. Sehingga temuan penelitian ini menunjukan bahwa penerapan model pembelajaran dan minat baca berpe- ngaruh pada pencapaian hasil belajar apresiasi puisi.

Pengujian normalitas data penelitian dilakukan terhadap delapan kelompok data, yaitu (1) A1, (2) A2, (3) B1, (4) B2, (5) A1B1, (6) A1B2, (7) A2B1, (8) dan A2B2. Uji normalitas data dilakukan dengan uji kolmogorov-Smirnov dengan taraf signifikansi $\alpha=0,05$.

Semua kelompok data yang diuji normalitasnya dengan One-Sample Kolmogorov-Smirnov Test dengan SPSS memberikan nilai signifikansipada baris Asymp. Sig (2-tailed) adalah masingmasing $0,797,0,667,0,818,0,801$, $0,533,0,230,0,552, \quad$ dan

0.337 , maka semua nilai memiliki $>0,05$. Dengan demikian disimpulkan bahwa delapan kelompok data dalam penelitian ini berasal dari populasi yang berdistribusi normal. Hal ini menunjukkan bahwa salah satu prasyarat uji $\mathrm{F}$ dalam penelitian telah terpenuhi.

Pengujian homogenitas varians menggunakan uji levenu's yaitu untuk mengetahui apakah data penelitian yang telah dikumpulkan berasal dari populasi yang homogen dengan taraf signifikasi $\alpha$ $=0,05$. Kriterianya adalah jika didapat signifikan hitung > signifikan tabel maka disimpulkan data homogen atau sebaliknya.

Pengujian homogenitas varians menggunakan uji levenu'syaitu untuk mengetahui apakah data penelitian yang telah dikumpulkanberasal dari populasi yang homogen dengan taraf signifikasi $\alpha$ $=0,05$. Kriterianya adalah jika didapat signifikan hitung > signifikan tabel maka disimpulkan data homogen atau sebaliknya.

Persyaratan bahwa data homogen adalah jika nilai sig > 0,05, maka hipotesis nol (Ho) diterima sesuai persyaratan. Hasil uji homogenitas 
terhadap kelompok data antara A1 dan A2 diperoleh nilai sig 0,094 yang berarti nilai sig > 0,05. Maka dapat disimpulkan bahwa data skor Hasil belajar apresiasi puisi dari kelompok data antara A1 dan A2 memiliki variansi populasi yang homogen.

Hasil uji homogenitas terhadap kelompok data antara A1 dan A2 diperoleh nilai sig 0,094 yang berarti nilai sig >0,05. Maka dapat disimpulkan bahwa data skor Hasil belajar apresiasi puisi dari kelompok data antara A1 dan A2 memiliki variansi populasi yang homogen.

Hasil uji homogenitas terhadap kelompok data antara B1 dan B2 diperoleh nilai sig 0,233 yang berarti nilai sig $>0,05$. Makadapat disimpulkan bahwa data skor Hasil belajar apresiasi puisi dari kelompok data antara B1 dan B2 memiliki variansi populasi yang homogen.

Hasil uji homogenitas terhadap kelompok data $(\mathrm{A}+\mathrm{B}+\mathrm{A} * \mathrm{~B})$ diperoleh nilai sig 0,299 yang berarti nilai sig > 0,05.Makadapat disimpulkan bahwa data skor Hasil belajar apresiasi puisi dari tiga kelompok data memiliki variansi populasi yang sama atau dengan kata lain data seluruh kelompok perlakuan berasal dari populasi yang homogen.

Pengujian hipotesis penelitian ini dilakukan dengan teknik analisis Anava dua jalan dengan bantuan program SPSS. Setelah dilakukan perhitungan jika kemudian ditemukan adanya interaksi maka dilanjutkan dengan uji Tuckey.

Hipotesis pertama menyatakan "Terdapat pengaruh yang signifikan model pembelajaran CTL terhadap hasil belajar apresiasi puisi siswa kelas VII Sekolah Menengah Pertama Negeri (SMPN) di Kabupaten Karawang”.

Berdasarkan hasil pengujian pada Tabel Test of Between-Subject Effects yang merupakan tabel utama yang mempresentasikan hasil hipotesis yang diajukan peneliti. Dari tabel tersebut, diketahui nilai p-value untuk kategori Model adalah 0,000 $(<0,05)$, maka dapat diartikan terdapat perbedaan yang signifikan hasil belajar apresiasi puisi pada penerapan model pembelajaran kontekstual dan model pembelajaran konvensional. Sehingga disimpulkan terdapat pengaruh yang signifikan model pembelajaran CTL terhadap hasil belajar apresiasi puisi siswa kelas VII Sekolah Menengah Pertama Negeri (SMPN) di Kabupaten Karawang.

Hipotesis pertama menyatakan "Terdapat pengaruh yang signifikan model pembelajaran CTL terhadap hasil belajar apresiasi puisi siswa kelas VII Sekolah Menengah Pertama Negeri (SMPN) di Kabupaten Karawang".

Berdasarkan hasil pengujian pada Tabel Test of Between-Subject Effects yang merupakan tabel utama yang mempresentasikan hasil hipotesis yang diajukan peneliti. Dari tabel tersebut, diketahui nilai $p$-value untuk kategori Model adalah 0,000 $(<0,05)$, maka dapat diartikan terdapat perbedaan yang signifikan hasil belajar apresiasi puisi pada penerapan model pembelajaran kontekstual dan model pembelajaran konvensional. Sehingga disimpulkan terdapat pengaruh yang signifikan model pembelajáran CTL terhadap hasil belajar apresiasi puisi siswa kelas VII Sekolah Menengah Pertama Negeri (SMPN) di Kabupaten Karawang.

Hipotesis ketiga menyatakan "Terdapat pengaruh interaktif yang signifikan model pembelajaran CTL dan minat baca siswa terhadap hasil belajar apresiasi puisi siswa kelas VII Sekolah Menengah Pertama Negeri (SMPN) di Kabupaten Karawang”. 
Berdasarkan hasil pengujian yang terdapat pada tabel Test of BetweenSubject Effects diperoleh nilai p-value untuk interaksi Model dan Minat baca $(\mathrm{A} * \mathrm{~B})$ adalah $0,001 \quad(<0,05)$, maka kesimpulannya terdapat pengaruh signifikan faktor interaksi kategori model pembelajaran (model kontekstual dan konvensional) dengan minat baca (tinggi dan rendah). Dengan demikian disimpulkan terdapat pengaruh interaksi model pembelajaran dan minat baca terhadap hasil belajar apresiasi puisi siswa kelas VII Sekolah Menengah Pertama Negeri (SMPN) di Kabupaten Karawang.

Hasil pengujian disimpulkan terdapat pengaruh interaksi model pembelajaran dan minat baca terhadap hasil belajar apresiasi puisi siswa kelas VII Sekolah Menengah Pertama Negeri (SMPN) di Kabupaten Karawang, maka dilakukan uji lanjut dengan uji Tukey yang dilakukan dengan bantuan program SPSS.

Kriteria pengujiannya adalah

-Tolak Ho dan terima $\mathrm{H}_{1}$ : jika $\mathrm{Sig}>$ 0,05

-Terima Ho dan tolak $\mathrm{H}_{1}$ : jika Sig < 0,05

Perbedaan antara Hasil belajar apresiasi puisi yang diberi model pembelajaran kontekstual pada siswa yang memiliki minat baca tinggi (A1B1) dengan Hasil belajar apresiasi puisi yang diberi model pembelajaran kontekstual pada siswa yang memiliki minat baca rendah (A1B2).

Hasil pengujian diperoleh sig = 0,027, maka Ho ditolak karena nilai Signifikansi (Sig) > 0,05. Dengan demikian disimpulkan terdapat perbedaan yang signifikan antara hasil belajar apresiasi puisi yang diberi model pembelajaran kontekstual pada siswa yang memiliki minat baca tinggi (A1B1) dengan hasil belajar apresiasi puisi yang diberi model pembelajaran kontekstual pada siswa yang memiliki minat baca rendah (A1B2)

Perbedaan antara Hasil belajar apresiasi puisi yang diberi model pembelajaran kontekstual pada siswa yang memiliki minat baca tinggi (A1B1) dengan Hasil belajar apresiasi puisi yang diberi model pembelajaran konvensional pada siswa yang memiliki minat baca tinggi (A2B1).

Hasil pengujian diperoleh nilai Sig = 0,161, maka Ho diterima karena nilai Sig $>0,05$. Dengan demikian disimpulkan tidak terdapat perbedaan yang signifikan antara hasil belajar apresiasi puisi yang diberi model pembelajaran kontekstual pada siswa yang memiliki minat baca tinggi (A1B1) dengan hasil belajar apresiasi puisi yang diberi model pembelajaran konvensional pada siswa yang memiliki minat baca tinggi (A2B1).

Perbedaan antara hasil belajar apresiasi puisi yang diberi model pembelajaran kontekstual pada siswa yang memiliki minat baca rendah (A1B2) dengan Hasil belajar apresiasi puisi yang diberi model pembelajaran konvensional pada siswa yang memiliki minat baca rendah (A2B2).

Hasil pengujian diperoleh nilai sig $=$ 0,000 , maka Ho ditolak karena nilai sig < 0,05 Dengan demikian disimpulkan terdapat perbedaan yang signifikan antara Hasil belajar apresiasi puisi yang diberi model pembelajaran kontekstual pada siswa yang memiliki minat baca rendah (A1B2) dengan Hasil belajar apresiasi puisi yang diberi model pembelajaran Konvensional pada siswa yang memiliki Minat baca rendah (A2B2).

Perbedaan antara hasil belajar apresiasi puisi yang diberi model 
pembelajaran konvensional pada siswa yang memiliki minat baca tinggi (A2B1) dengan Hasil belajar apresiasi puisi yang diberi model pembelajaran konvensional pada siswa yang memiliki Minat baca rendah (A2B2).

Hasil pengujian nilai sig $=0,000$, maka Ho ditolak nilai sig > 0,05. Dengan demikian disimpulkan terdapat perbedaan yang signifikan antara Hasil belajar apresiasi puisi yang diberi model pembelajaran konvensional pada siswa yang memiliki minat baca tinggi (A2B1) dengan Hasil belajar apresiasi puisi yang diberi model pembelajaran konvensional pada siswa yang memiliki minat baca rendah (A2B2).

Hasil pengujian uji lanjut dengan uji tukey diperoleh:

a. Terdapat perbedaan yang signifikan antara Hasil belajar apresiasi puisi yang diberi model pembelajaran kontekstual pada siswa yang memiliki minat baca tinggi (A1B1) dengan Hasil belajar apresiasi puisi yang diberi model pembelajaran kontekstual pada siswa yang memiliki minat baca rendah (A1B2). Hasil pengujian diperoleh sig $=0,027$, maka $\mathrm{Ho}$ ditolak karena Sig < 0,05.

b. Tidak terdapat Perbedaan yang signifikan antara Hasil belajar apresiasi puisi yang diberi model pembelajaran kontekstual pada siswa yang memiliki minat baca tinggi (A1B1) dengan Hasil belajar apresiasi puisi yang diberi model pembelajaran konvensional pada siswa yang memiliki minat baca tinggi (A2B1). Hasilpengujian diperoleh nilai Sig = 0,161, maka Ho diterima karena nilai Sig $>0,05$.

c. Terdapat perbedaan yang signifikan antara Hasil belajar apresiasi puisi yang diberi model pembelajaran kontekstual pada siswa yang memiliki minat baca rendah (A1B2) dengan Hasil belajar apresiasi puisi yang diberi model pembelajaran konvensional pada siswa yang memiliki minat baca rendah (A2B2). Hasil pengujian diperoleh nilai sig $=0,000$, maka Ho ditolak karena nilai sig < 0,05 .

d. Terdapat perbedaan yang signifikan antara hasil belajar apresiasi puisi yang diberi model pembelajaran konvensional pada siswa yang memiliki minat baca tinggi (A2B1) dengan Hasil belajar apresiasi puisi yang diberi model pembelajaran konvensional pada siswa yang memiliki minat baca rendah (A2B2). Hasil pengujian diperoleh nilai sig $=$ 0,000, maka Ho ditolak karena nilai sig $<0,05$.

Penelitian ini mendukung teori bahwa pemberian model pembelajarankooperatif seperti model kontekstual mempengaruhi hasil belajar apresiasi puisi. Banyak faktor yang dapat meningkatkan hasil belajar siswa khususnya dalam pelajaran sastra. Oleh karena itu, dalam memberikan materi pelajaran sastra, seorang guru harus pandai-pandai dalam merancang model pembelajaran yang dapat menarik siswa. Pemilihan model pembelajaran yang dilaksanakan seorang guru merupakan bagian dari kreativitas guru dalam melaksanakan pembelajaran yang efektif dan inovatif yang dapat menghilangkan rasa jenuh siswa.Secara teknis model pembelajaran berfungsi sebagai sumber belajar bagi peserta didik dan memungkinkan atau memudahkan terjadinya proses belajar, baik secara individu maupun kelompok. Dengan demikian model pembelajaran tersebut diharapkan dalam beberapa hal dapat 
menggantikan fungsi guru terutama sebagai sumber belajar.

Kemampuan merancang model pembelajaran tidak begitu saja bisa dilaksanakan, tanpa adanya keinginan dari dalam diri guru untuk senantiasa meningkatkan kemampuan dan wawasannya dalam bidang pendidikan khususnya pembelajaran di kelas. Untuk mewujudkan hal tersebut, diperlukan dorongan yang kuat dari dalam diri guru itu sendiri.

Begitu pula bagi siswa yang terlibat dalam proses pembelajaran yang sedang berlangsung. Mereka diharapkan memiliki minat baca yang tinggi. Minat baca adalah pilihan kesenangan dalam melakukan kegiatan dan dapat membangkitkan gairah seseorang untuk memenuhi kesediannya dalam membaca.

Minat baca yang melekat pada diri mereka sebaiknya memiliki kesinambungan dengan model pembelajaran yang diterapkan oleh guru agar Hasil belajar apresiasi puisi mereka mendapat hasil seperti yang diharapkan.

Berdasarkan teori tersebut dapat diartikan bahwa pemberian model pembelajaran yangdapat meningkatkan hasil belajar apresiasi puisi. Siswa dengan berbagai latar belakang seperti yang memiliki minat baca tinggi maupun rendahdalam penelitian ini mampu meningkatkan hasil belajar apresiasi puisi. Sehingga temuan penelitian ini menunjukan bahwa penerapan model pembelajaran dan minat baca berpengaruh pada pencapaian hasil belajar apresiasi puisi.

Hasil belajar apresiasi puisi di atas rata-rata, 18,2\% siswa memperoleh hasil belajar berada pada rata-rata, dan
40,9\% siswa memperoleh hasil belajar di bawah rata-rata.

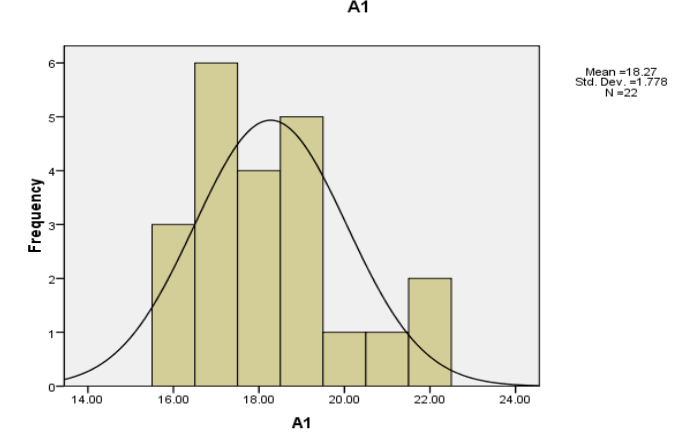

\section{Histogram hasil belajar apresiasi puisi pada kelompok siswa yang diberi model pembelajaran Kontekstual (A1)}

Dari 22 orang siswa sebagai sampel penelitian dalam kelompok yang diberi model pembelajaran konvensional (A2) diperoleh nilai rerata 59,27 dan standar deviasi 11,82. Berdasarkan distribusi frekuensi dan histogram di bawah ini terlihat terdapat $50 \%$ siswa memperoleh Hasil belajar apresiasi puisi di atas ratarata, $4,5 \%$ siswa memperoleh hasil belajar berada pada rata-rata, dan $45,5 \%$ siswa memperoleh hasil belajar di bawah rata-rata.

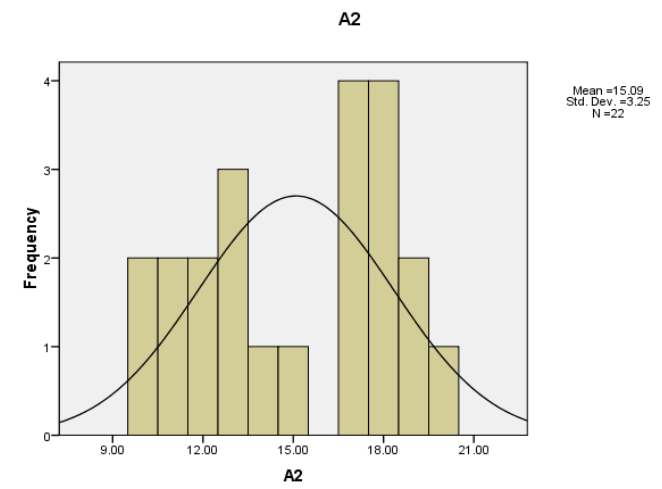

Histogram hasil belajar apresiasi puisi pada kelompok siswa yang diberi model pembelajaran Konvensional (A2) 
Dari 22 orang siswa sebagai sampel penelitian dalam kelompok yang memiliki minat baca tinggi (B1) diperoleh nilai rerata 74,18 dan standar deviasi 6,95. Berdasarkan distribusi frekuensi dan histogram di bawah ini terlihat terdapat $50 \%$ siswa memperoleh hasil belajar apresiasi puisi di atas ratarata, $18,2 \%$ siswa memperoleh hasil belajar berada pada rata-rata, dan $31,8 \%$ siswa memperoleh hasil belajar di bawah rata-rata.

B1

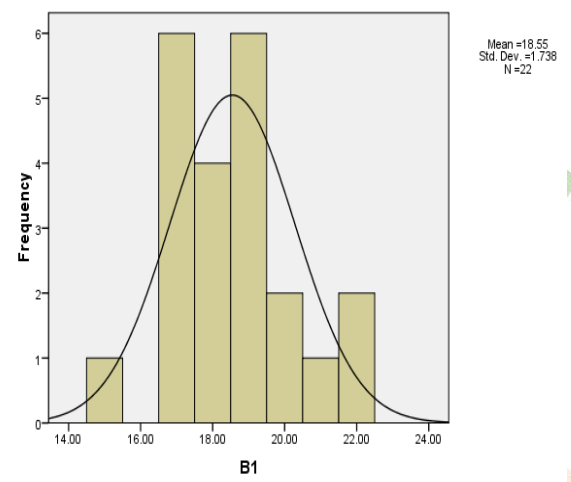

Histogram hasil belajar apresiasi puisi pada kelompok siswa yang memiliki minat baca tinggi (B1)

Dari tabel di atas bahwa dari 22 orang siswa sebagai sampel penelitian dalam kelompok yang memiliki minat baca rendah (B2) diperoleh nilai rerata 59,27 dan standar deviasi 11,82. Berdasarkan distribusi frekuensi dan $_{k c}$ histogram 4.di bawah ini terlihat terdapatic $54,5 \%$ siswa memperoleh Hasil belajar apresiasi puisi di atas rata-rata, 4,5\% siswa memperoleh hasil belajar berada pada rata-rata, dan $40,9 \%$ siswa memperoleh hasil belajar di bawah ratarata.

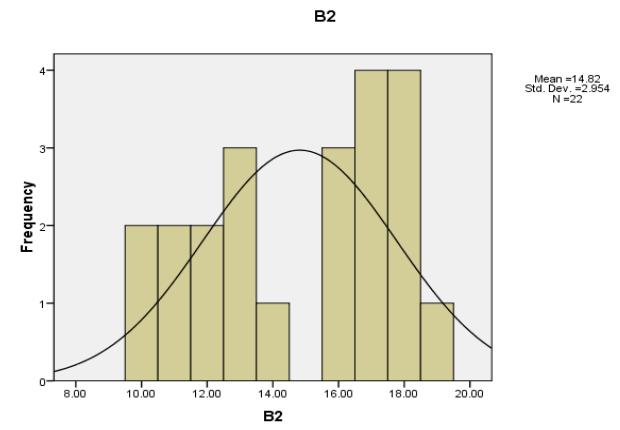

Histogram hasil belajar apresiasi puisi pada kelompok siswa yang memiliki minat baca rendah (B2)

Dari 11 orang siswa sebagai sampel penelitian dalam kelompok yang diberi model pembelajaran kontekstual dan memiliki minat baca tinggi (A1B1) diperoleh nilai rerata 77,09 dan standar deviasi 7,40. Berdasarkan distribusi frekuensi dan histogram 4.5. di bawah ini terlihat terdapat $36,4 \%$ siswa memperoleh Hasil belajar apresiasi puisi di atas rata-rata, $36,4 \%$ siswa memperoleh hasil belajar berada pada rata-rata, dan $27,3 \%$ siswa memperoleh hasil belajar di bawah rata-rata.

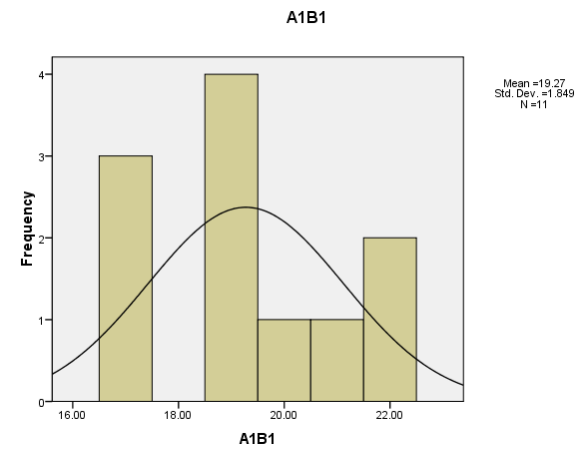

Histogram hasil belajar apresiasi puisi pada kelompok yang diberimodel pembelajaran kontekstual, dan yang memiliki minat baca tinggi (A1B1)

Dari 11 orang siswa sebagai sampel penelitian dalam kelompok hasil belajar apresiasi puisi pada kelompok siswa 
yang diberi model pembelajaran kontekstual dan memiliki minat baca rendah (A1B2), diperoleh nilai rerata 69,09 dan standar deviasi 4,04. Berdasarkan tabel disitribusi dan histogram 4.6 di bawah ini terdapat $45,5 \%$ siswa memperoleh hasil belajar di atas rata-rata, 27,3\% siswa memperoleh hasil belajar pada rata-rata, dan $27,3 \%$ siswa memperoleh hasil belajar di bawah rata-rata.

$\mathrm{A} 1 \mathrm{~B} 2$

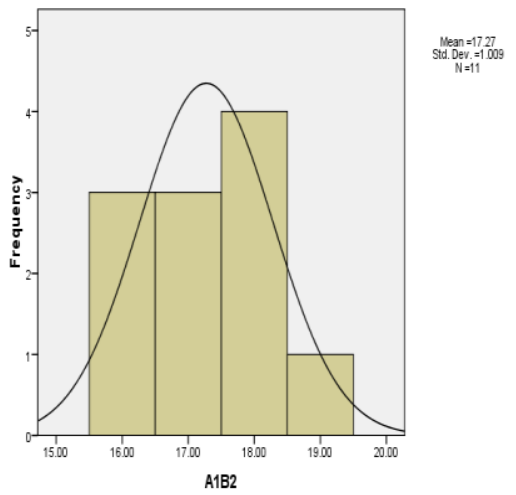

Histogram hasil belajar apresiasi puisi pada kelompok yang diberimodel pembelajaran kontekstual, dan yang memiliki minat baca rendah (A1B2)

Dari 11 orang siswa sebagai sampel penelitian dalam kelompok hasil belajar apresiasi puisi dengan model pembelajaran konvensional yang memiliki minat baca tinggi (A2B1), diperoleh nilai rerata 71,27 dan standar deviasi 6,31. Berdasarkan Petabel disitribusi dan histogram 4.7 di bawah terdapat $63,6 \%$ siswa memperoleh hasil belajar di atas rata-rata, 27,3\% siswa memperoleh hasil belajar pada rata-rata, dan $9,1 \%$ siswa memperoleh hasil belajar di bawah rata-rata.

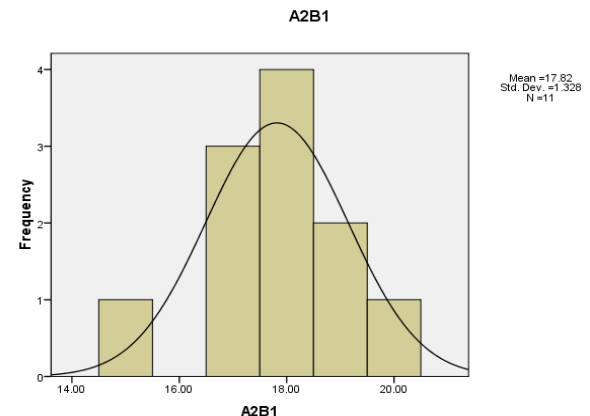

Histogram Skor hasil belajar apresiasi puisi pada kelompok yang

diberipembelajaran konvensional dan memiliki minat baca tinggi (A2B1)

Dari 11 orang siswa sebagai sampel penelitian dalam kelompok hasil belajar apresiasi puisi yang diberi model pembelajaran konvensional dan memiliki minat baca rendah (A2B2), diperoleh nilai rerata 49,45 dan standar deviasi 8,05. Berdasarkan tabel disitribusi dan histogram 4.8 di bawah terdapat $45,4 \%$ siswa memperoleh hasil belajar di atas rata-rata, $18,2 \%$ siswa memperoleh hasil belajar pada rata-rata, dan $36,4 \%$ siswa memperoleh hasil belajar di bawah ratarata.

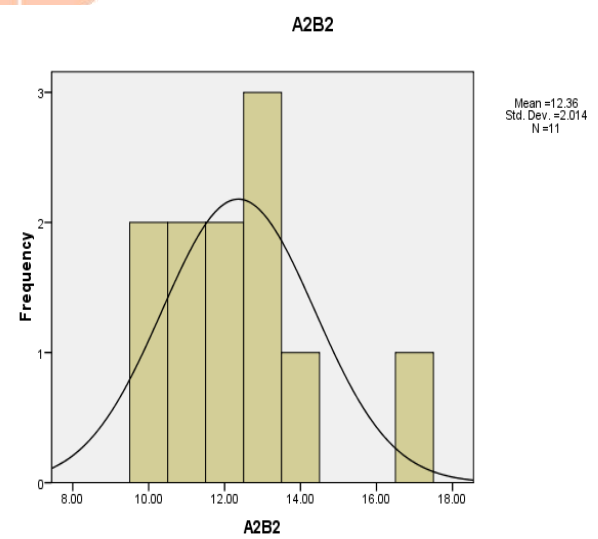

Histogram Skor hasil belajar apresiasi puisi pada kelompok yang

diberipembelajaran konvensional dan memiliki minat baca rendah (A2B2) 
Untuk kategori pemberian model pembelajaran kontekstual pada siswa dengan minat tinggi memiliki nilai ratarata hasil belajar lebih tinggi dibandingkan nilai rata-rata hasil belajar siswa dengan minat rendah. Sedangkan untuk kategori pemberian model pembelajaran konvensional dengan minat baca tinggi memiliki nilai rata-rata hasil belajar apresiasi puisi lebih tinggi dibandingkan dengan kelompok siswa dengan minat baca rendah. Dengan demikian dapat diartikan pemberian model pembelajaran kontekstual dapat meningkatkan hasil belajar apresiasi puisi.

\section{Tabel}

Data hasil penelitian berupa Hasil belajar apresiasi puisi $(\mathrm{Y})$ sebagai akibat dari perlakukan penelitian $\left(\mathrm{X}_{1}\right)$, yaitu penggunaan pendekatan Model Pembelajaran (A), berupa pendekatan model Kontekstual $\left(\mathrm{A}_{1}\right)$ dan model Konvensional $\left(\mathrm{A}_{2}\right)$, serta pendekatan minat baca terhadap Hasil belajar apresiasi puisi $\left(\mathrm{X}_{2}\right)$, dibedakan menjadi minat baca tinggi $\left(\mathrm{B}_{1}\right)$, dan Minat baca rendah $\left(B_{3}\right)$. Data hasil penelitian dianalisis dengan teknik statistik deskriptif, untuk mengukur tendensi sentral dan tendensi penyebaran data dari setiap kelompok perlakuan. Perhitungan data hasil penelitian dilakukan dengan menggunakan program olah data ${ }^{2}$ Xaitu "SPSS".

Tabel 1.

Rekapitulasi Hasil Perhitungan Skor Hasil Belajar Apresiasi Puisi dan Minat

Baca

\begin{tabular}{|c|l|l|l|}
\hline $\begin{array}{l}\text { Model } \\
\begin{array}{l}\text { Pemberlajaran } \\
\text { Minat baca }\end{array}\end{array}$ & $\begin{array}{c}\text { Kontekstual } \\
\text { (CTL) }\end{array}$ & \multicolumn{1}{|c|}{ K2 } & \multirow{2}{*}{$\begin{array}{c}\text { Kumlah Baris } \\
(\Sigma \mathrm{B})\end{array}$} \\
\hline B1 & $\mathrm{n}=11$ & $\mathrm{n}=11$ & \\
$\begin{array}{c}\text { MinatBaca } \\
\text { Tinggi }\end{array}$ & $\bar{X}=77,09$ & $\bar{X}=71,27$ & $\mathrm{n}=22$ \\
& $S=7,40$ & $S=5,31$ & $S=74,18$ \\
& & & \\
\hline B2 & $\mathrm{n}=11$ & $\mathrm{n}=11$ & $\mathrm{n}=22$ \\
\hline
\end{tabular}

\begin{tabular}{|c|l|l|l|}
\hline $\begin{array}{c}\text { Minat Baca } \\
\text { Rendah }\end{array}$ & $\bar{X}=69,09$ & $\bar{X}=49,45$ & $\bar{X}=59,27$ \\
$S=4,04$ & $S=8,05$ & $S=11,82$ \\
\hline Jumlah & $\mathrm{n}=22$ & $\mathrm{n}=22$ & $\mathrm{n}=44$ \\
Kolom & $\bar{X}=73,09$ & $\bar{X}=60,36$ & $\bar{X}=66,73$ \\
$(\Sigma \mathrm{K})$ & $S=7,11$ & $S=13,00$ & $S=12,19$ \\
\hline
\end{tabular}

\section{PENUTUP}

\section{Simpulan}

Berdasarkan data yang diperoleh, hasil pengujian hipotesis dan pembahasan hasil penelitian, maka dapat disimpulkan:

1. Terdapat pengaruh yang signifikan model pembelajaran terhadap hasil belajar apresiasi puisi siswa di SMP Negeri Kabupaten Karawang. Hal tersebut dapat dibuktikan dengan nilai Sig $=0,000(<0.05)$ dan F hitung = 43.440 , maka terdapat perbedaan yang signifikan terhadap hasil belajar apresiasi puisi pada penerapan model pembelajaran kontekstual dan model pembelajaran konvensional.

2. Terdapat pengaruh yang signifikan minat baca terhadap hasil belajar apresiasi puisi siswa di SMP Negeri Kabupaten Karawang. Hal tersebut dapat dibuktikan dengan nilai sig $=$ $0,000(<0.05)$ F hitung $=59.610$ yang berarti terdapat perbedaan yang signifikan terhadap hasil belajar apresiasi puisi pada siswa yang memiliki minat baca tinggi dan rendah.

3. Terdapat pengaruh interaksi yang signifikan model pembelajaran dan a minat baca terhadap hasil belajar apresiasi puisi siswa di SMP Negeri Kabupaten Karawang. Hal tersebut dapat dibuktikan dengan nilai $\mathrm{p}$-value untuk kategori interaksi model pembelajaran dan minat baca belajar $(\mathrm{A} * \mathrm{~B})$ adalah $0,001(<0.05) \mathrm{F}$ hitung $=12.801$, maka kesimpulannya terdapat perbedaan signifikan faktor interaksi kategori model pembelajaran (kontekstual dan konven- 
sional) dengan minat baca (tinggi dan rendah).

Hasil belajar apresiasi puisi yang diberi model pembelajaran kontekstual pada siswa yang memiliki minat baca tinggi memiliki nilai rata-rata tertinggi, sedangkan nilai terendah terjadi pada kelompok yang diberi model pembelajaran konvensional dengan minat baca rendah.

\section{Saran}

Berdasarkan pada simpulan penelitian di atas, maka berikut ini diajukan beberapa saran untuk perbaikan Hasil belajar apresiasi puisi siswa kelas VII Sekolah Menengah Pertama Negeri (SMPN) di Kabupaten Karawang sebagai berikut:

1. Hasil penelitian menunjukkan siswa yang diberi model kontekstual memiliki nilai rata-rata lebih tinggi dibandingkan dengan nilai rata-rata siswa yang diberi dengan pembelajaran konvensional. Untuk itu agar guru menjadikan model kontekstual sebagai alternatif dalam meningkatkan hasil belajar apresiasi puisi.

2. Guru dalam melaksanakan kegiatan belajar mengajar seharusnya mengunakan teknik atau model pembelajaran yang sesuai dengan

3. Guru hendaknya membiasakan dican Bahasa, Sastra kegiatan belajar pada siswanya untuk belajar berkelompok dalam belajar, dan setiap kelompok dipimpin oleh siswa yang memiliki minat baca tinggi.

\section{DAFTAR PUSTAKA}

Sukardi, Dewa Ketut. 1983. Bimbingan dan penyuluhan belajar di sekolah. Surabaya: Usaha Nasional.
Dharma, Surya. 2008. Penilaian hasil belajar. Jakarta: Direktorat Jenderal PMPTK Depdiknas.

Djaali, H. 2008. Psikologi pendidikan. Jakarta: PT Bumi Aksara.

Tarigan, Djago. 2003. Materi pokok pendidikan bahasa Indonesia II "pengajaran kosakata". Jakarta: Universitas Terbuka.

Djamarah, Syaiful Bahri. 2002. Psikologi belajar. Jakarta: Rineka Cipta.

Djojosuroto, Kinayanti, 2005. Puisi, pendekatan dan pembelajaran. Bandung: Nuasa.

Farida, Rahim. 2008. Pengajaran membaca di sekolah dasar. Jakarta: Bumi Aksara.

Kamah, Idris. 2013. Pedoman pembinaan minat baca. Jakarta. Pustaka.

Komarudin. 2001. Ensiklopedia manajemen, edisi ke-5. Jakarta: Bumi Aksara.

Nasution. 2006. Didaktik asas-asas mengajar. Bandung: Bumi Aksara.

Nurhadi. 2002. Contextual teaching and learning. Jakarta: Depdiknas Dirjen Dikdasmen Direktorat Pendidikan Lanjutan Pertama. 